\title{
Abandoned underground mines Risks and prevention: Presentation of the Seminar
}

\author{
M. TOULEMONT**
}

After a series of collapses of underground cavities which occurred in Paris between 1774 and 1776, the Council of State of King Louis XVI decided to create the so-called "Technical Service of underground mines", which was supposed to "compile mines beneath the city of Paris, draw up maps, supervise and achieve the required works".

The problem of the prevention of risks due to the damaging of underground mines was thus clearly settled, but Paris' example was only followed by a few districts or cities which were particularly threatened, although a great part of the French territory was actually concerned to various extents. According to an enquiry commissioned in 1994 by the Department of the Environment and the Home Office, it appeared that almost $10 \%$ of communities are undermined by underground mines. More than $20 \%$ of those communitics had to suffer during the 30 past years (1973-1993) from one or several-more or less serious-instability phenomena.

Such a percentage of accidents is not surprising when considering that the majority of those abandoned mines were left to the land-owners without any back filling or stabilization the mining regulations prior to 1971 did not allow any particular works, except right under communication routes or private and public buildings, where remedial measures could be prescribed, in order to secure public safety).

The underground mines were often mined to the very limits of stability and they represent an economical obstacle to the urban development of many cities as well as a threat for the safety of people and properties. The progressive urbanization of undermined areas, often situated in the periphery of urban centres, has often been achieved without properly sorting out stability problems, which led to hazardous situations, which are now difficult to manage. The prevention and management of those legacies of the past are now meeting with technical, institutional and operational problems, in front of which most public Communities are helpless. although supposed to be competent as regards planning and public safety.

- Firstly a technical problem : in many cases, the abandoned mines were unrecorded, and the knowledge of the underground has to be secured with the help of more or less reliable, and sometimes esoteric geophysical and geotechnical techniques.
- Secondly, an institutional problem: the State administrative responsabilities, as concerns city planning and public safety were transferred to districts some years ago.

The district is in particular responsible for taking the risks induced by the evolution of disused mines into account, when preparing land use plans and giving building permits. Moreover, mayors are responsible for safety, in their capacities of general or specific administrative regulations.

The state keeps its responsibilities as concerns the information on risks through specific statutory regulations. At the mayor's request, State authorities may also act within the bounds of the mining regulations.

If one considers the geographical extension of mines, it generally appears that the relevant institutional level should neither be the district, nor the whole country but the region, or several regions, but those administrative levels have no official competence in that field. even if some regions created technical services copied on the Paris "Technical service of underground mines".

- And finally an operational problem: faced with the technical and financial problems linked to the review of risks and their prevention, the majority of districts are unable to implement preventive and remedial measures, except when they can collect some financial helps from other public authorities.

Otherwise, and except in the districts or regions with technical services at their disposal, there is a limited number of statutory risks maps which might be opposed to development plans or building permits.

In order to review all those problems the French Home Office and the Department of Environment felt the need for a critical assessment of knowledge and present practice as concerns the prediction and prevention of risks as well as the management of crisis conditions. Therefore a seminar was organized, with experts, practitioners and decision-makers. It took place in Nainville-lesRoches, December 8-10, 1993.

The works of the seminar were shared between three thematic technical workshops. The results of the discussions are presented in the three following papers:

- Josien : "Analysis and description of risk";

- J.L. Durville and M. Hameroux : "Preventive strategies and methods";

- P. Masure : "Management of risks and crisis".

\footnotetext{
* Direction de la Prévention des pollutions et des risques, Sous-direction de la prévention des risques majeurs, Bureau risques naturels, 20, avenue de Ségur, 75302 Paris. 07-S.P.
} 